\title{
Genetic signature analysis of Perkinsus marinus in Mexico suggests possible translocation from the Atlantic Ocean to the Pacific coast of Mexico
}

Juan Pablo Ek-Huchim†, Ma. Leopoldina Aguirre-Macedo², Monica Améndola-Pimenta', Victor Manuel Vidal-Martínez², Juan Antonio Pérez-Vega', Raúl Simá-Alvarez², Isabel Jiménez-García, Roberto Zamora-Bustillos ${ }^{4}$ and Rossanna Rodríguez-Canul ${ }^{1 *+}$ (D)

\begin{abstract}
Background: The protozoan Perkinsus marinus (Mackin, Owen \& Collier) Levine, 1978 causes perkinsosis in the American oyster Crassostrea virginica Gmelin, 1791. This pathogen is present in cultured C. virginica from the Gulf of Mexico and has been reported recently in Saccostrea palmula (Carpenter, 1857), Crassostrea corteziensis (Hertlein, 1951) and Crassostrea gigas (Thunberg, 1793) from the Mexican Pacific coast. Transportation of fresh oysters for human consumption and repopulation could be implicated in the transmission and dissemination of this parasite across the Mexican Pacific coast. The aim of this study was two-fold. First, we evaluated the P. marinus infection parameters by PCR and RFTM (Ray's fluid thioglycollate medium) in C. virginica from four major lagoons (Términos Lagoon, Campeche; Carmen-Pajonal-Machona Lagoon complex, Tabasco; Mandinga Lagoon, Veracruz; and La Pesca Lagoon, Tamaulipas) from the Gulf of Mexico. Secondly, we used DNA sequence analyses of the ribosomal nontranscribed spacer (rNTS) region of P. marinus to determine the possible translocation of this species from the Gulf of Mexico to the Mexican Pacific coast.

Results: Perkinsus marinus prevalence by PCR was 57.7\% (338 out of 586 oysters) and 38.2\% (224 out of 586 oysters) by RFTM. The highest prevalence was observed in the Carmen-Pajonal-Machona Lagoon complex in the state of Tabasco (73\% by PCR and 58\% by RFTM) and the estimated weighted prevalence (WP) was less than 1.0 in the four lagoons. Ten unique rDNA-NTS sequences of $P$. marinus [termed herein the "P. marinus (Pm) haplotype"] were identified in the Gulf of Mexico sample. They shared 96-100\% similarity with 18 rDNA-NTS sequences from the GenBank database which were derived from 16 Mexican Pacific coast infections and two sequences from the USA. The phylogenetic tree and the haplotype network showed that the P. marinus rDNA-NTS sequences from Mexico were distant from the rDNA-NTS sequences of $P$. marinus reported from the USA. The ten rDNA-NTS sequences described herein were restricted to specific locations displaying different geographical connections within the Gulf of Mexico; the Carmen-Pajonal-Machona Pm1 haplotype from the state of Tabasco shared a cluster with P. marinus isolates reported from the Mexican Pacific coast.

(Continued on next page)
\end{abstract}

\footnotetext{
* Correspondence: rossana.rodriguez@cinvestav.mx

${ }^{\dagger}$ Equal contributors

'Laboratorio de Inmunología y Biología Molecular, Centro de Investigación y

de Estudios Avanzados del IPN (CINVESTAV-IPN) Unidad Mérida, Carretera

Antigua a Progreso Km. 6, 97310 Mérida, Yucatán, Mexico

Full list of author information is available at the end of the article
} 
(Continued from previous page)

Conclusions: The rDNA-NTS sequences of $P$. marinus from the state of Tabasco shared high similarity with the reference rDNA-NTS sequences from the Mexican Pacific coast. The high similarity suggests a transfer of oysters infected with P. marinus from the Mexican part of the Gulf of Mexico into the Mexican Pacific coast.

Keywords: Perkinsus marinus, Crassostrea virginica, Gulf of Mexico, Transfer, Mexican Pacific coast

\section{Background}

The protozoan Perkinsus marinus (Mackin, Owen \& Collier) Levine, 1978 (Phylum Perkinsozoa) is one of the main pathogens of the American oyster Crassostrea virginica Gmelin, 1971 [1], causing perkinsosis. This pathogen is listed as notifiable by the World Organization for Animal Health (OIE) (http://www.oie.int/en/animal-health-in-theworld/oie-listed-diseases-2016/). Perkinsosis is associated with high mortality of populations of $C$. virginica [1-5]. The distribution of $C$. virginica infected with $P$. marinus from the southeastern coast of the USA portion of the Gulf of Mexico to the central, and northern USA Atlantic seaboard is well documented. To date, P. marinus remains a threat to $C$. virginica populations in these regions $[3,6$, 7]. This parasite also caused major economic losses after its accidental introduction into Pearl Harbor, Hawaii [8]. In Brazil, $P$. marinus has been found infecting the mangrove oysters Crassostrea rhizophorae (Guilding, 1828) [9-11] and Crassostrea gasar (Deshayes, 1830) [9]. Perkinsus marinus has also been detected in Panamanian waters infecting $C$. virginica and $C$. rhizophorae in the Caribbean canal and C. columbiensis (Hanley, 1846) from the Pacific coast [12]. In Mexico, P. marinus has been reported in $C$. virginica from the Mexican coast of the Gulf of Mexico [3, 13-16]. In 1992 P. marinus was alleged to cause mortality of $C$. virginica stocks from the state of Tabasco, but prevalence and intensity of infection in the Gulf of Mexico, vary with location and season whether assessed either by Ray's Fluid Thioglycollate Medium (RFTM) assay or PCR [3, $13-15,17,18]$. The RFTM assay is highly useful to determine infection level and is considered the gold standard technique by the OIE [19]. Additionally, the nontranscribed spacer (NTS) is used as an rDNA marker to identify and discriminate between Perkinsus species using PCR [20, 21]. The two tests can be used together to increase the chance of detecting perkinsosis.

Perkinsus marinus is prevalent in the Gulf of Mexico [3, 13-15], but there was no evidence for its presence in the Mexican Pacific coast until 2006 when P. marinus caused high mortality in Crassostrea corteziensis (Hertlein, 1951) in the state of Nayarit [21] and Crassostrea gigas (Thunberg, 1793) in the state of Sonora [22], from Mexico's Pacific coast. These outbreaks showed that oyster species appear to vary in their susceptibility to $P$. marinus; its pathogenicity and virulence could be associated with DNA molecular variability. This hypothesis is supported by the finding that low and transient infections were found in Saccostrea palmula (Carpenter, $1857)$ in the same areas [7, 23-28].

The adverse ecological and financial effects of the introduction of a given disease into a new geographical area are always a cause for concern. Importantly, bivalves are both hosts and vectors of microparasites, including $P$. marinus [29]. The spread of perkinsosis with the transport of live oysters for repopulation, commercialization and aquaculture purposes has devastated native and cultured species causing severe epizootics [9].

The aims of this study were to evaluate the presence of DNA variants of $P$. marinus and to assess the infection parameters of $P$. marinus in four coastal lagoons in the Gulf of Mexico, where $C$. virginica commercialization is highly profitable. We also appraised the transfer connection between $P$. marinus isolates from the Gulf of Mexico and those reported in the Mexican Pacific by analysing DNA sequences from the NTS region.

\section{Results}

Infection parameters of Perkinsus marinus in lagoons from the Gulf of Mexico

Overall, the prevalence of $P$. marinus in the four lagoons was $57.7 \%$ (338 out of 586 oysters) using PCR and $38.4 \%$ (225 out of 586 oysters) using RFTM. PCR had a sensitivity of $93.8 \%$ and a specificity of $94.4 \%$, while the RFTM showed $62.4 \%$ sensitivity and $64.8 \%$ specificity. Significant differences were observed by comparing both prevalences (Chi-square test, $\chi^{2}=194.98, d f=1$, $P<0.0001)$. The highest prevalence was observed in the state of Tabasco (G-test, $G=20.04, d f=3, P=0.00016$ 6). Infection intensities were characterized as light (1-10 hypnospores/field) to moderate infection (11-100 hypnospores/field). Weighted prevalence (WP) values less than 1.0 indicated mostly light infections (Table 1).

\section{Términos Lagoon, Campeche}

The prevalence was $48.3 \%$ (58 out of 120 oysters) using PCR and $6.7 \%$ (8 out of 120 oysters) using RFTM (Fig. 1). All organisms that were positive using the RFTM assay were positive by PCR, but $41.7 \%$ (50/120) of the oysters that were positive using PCR were negative by RFTM, and 41.7\% (50/ 120) were negative for both tests $\left(\chi^{2}=9.16, d f=1\right.$, 
Table 1 Parameter values of Perkinsus marinus in Crassostrea virginica. Prevalence, sensitivity and specificity in each lagoon were assessed by Ray's Fluid Thioglycollate Medium (RFTM) and Polymerase Chain Reaction (PCR). Weighted prevalence (WP) was addressed by RFTM

\begin{tabular}{|c|c|c|c|c|c|c|c|c|c|c|c|c|}
\hline \multirow[t]{2}{*}{ Lagoon } & \multirow[t]{2}{*}{$\begin{array}{l}\text { Oysters } \\
\text { sampled }\end{array}$} & \multicolumn{2}{|c|}{$\begin{array}{l}\text { Prevalence } \\
\text { (\%) }\end{array}$} & \multicolumn{2}{|c|}{$\begin{array}{l}\text { Sensitivity } \\
(\%)\end{array}$} & \multicolumn{2}{|c|}{$\begin{array}{l}\text { Specificity } \\
(\%)\end{array}$} & \multirow[t]{2}{*}{ WP } & \multirow[t]{2}{*}{$\begin{array}{l}\text { No. of DNA } \\
\text { sequences }\end{array}$} & \multicolumn{2}{|c|}{ P. marinus haplotypes } & \multirow[t]{2}{*}{$\begin{array}{l}\text { Accession } \\
\text { number }\end{array}$} \\
\hline & & RFTM & $P C R$ & RFTM & $P C R$ & RFTM & $P C R$ & & & No. of haplotypes & Code (frequency) & \\
\hline \multirow[t]{2}{*}{ Términos } & 120 & 6.7 & 48.3 & 13.8 & 100.0 & 55.4 & 100.0 & 0.07 & 20 & 2 & Pm18 (11) & KX581121 \\
\hline & & & & & & & & & & & Pm88 (9) & KX581120 \\
\hline Carmen-Pajonal-Machona & 300 & 60.0 & 73.0 & 79.5 & 97.2 & 62.8 & 93.8 & 0.69 & 10 & 1 & Pm1 (10) & KX581119 \\
\hline \multirow[t]{5}{*}{ Mandinga } & 75 & 25.3 & 46.7 & 51.4 & 94.7 & 69.6 & 97.5 & 0.25 & 20 & 5 & Pm1 (5) & KX581118 \\
\hline & & & & & & & & & & & Pm2 (5) & KX581117 \\
\hline & & & & & & & & & & & Pm3 (4) & KX581115 \\
\hline & & & & & & & & & & & Pm4 (3) & KX581116 \\
\hline & & & & & & & & & & & Pm10 (3) & KX581113 \\
\hline \multirow[t]{2}{*}{ La Pesca } & 91 & 19.8 & 28.6 & 42.3 & 61.1 & 79.5 & 89.2 & 0.19 & 30 & 2 & Pm27 (15) & KX581114 \\
\hline & & & & & & & & & & & Pm30 (15) & KX581112 \\
\hline
\end{tabular}

$P=0.0025)$. The sensitivity and specificity of PCR were both $100 \%$, but using RFTM, they were only 13.8 and $55.4 \%$, respectively. Infection intensity was light (1-10 hypnospores/ field) in eight oysters, and the WP was 0.07 (Table 1).

\section{Carmen-Pajonal-Machona Lagoon Complex, Tabasco}

The prevalence using PCR was 73\% (219 out of 300 oysters), and it was $60 \%$ using RFTM (180 out of 300 oysters) (Fig. 1). In total, 58\% (174/300) were positive by both tests, while 15\% (45/300) were RFTM-negative but PCR-positive and $1.7 \%$ (5/300) were positive by RFTM but negative by
PCR $\left(\chi^{2}=131.94, d f=1, P<0.0001\right)$. The sensitivity and specificity of the PCR method were $97.2 \%$ and $93.8 \%$, respectively, and using RFTM; these values were 79.5 and $62.8 \%$, respectively. Infection intensity was light (1-10 hypnospores/field) in 161 oysters, while in 4.3\% (13/300), it was moderate (11-100 hypnospores/field), resulting in a WP of 0.69 for this lagoon (Table 1 ).

\section{Mandinga Lagoon, Veracruz}

The prevalence using PCR was $46.7 \%$ (35 out of 75 oysters), and the prevalence was $25.3 \%$ (19 o ut of 75

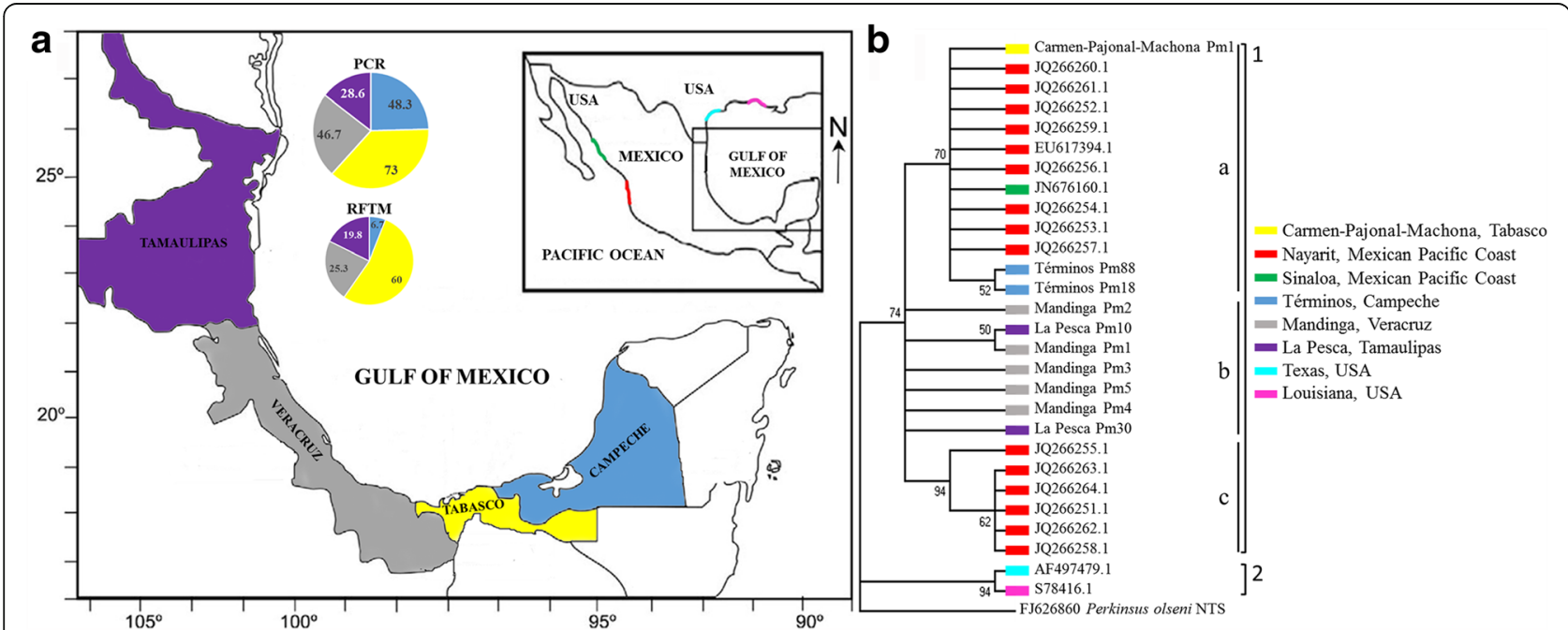

Fig. 1 Study site locations from the Mexican Gulf of Mexico: a Términos Lagoon, Campeche; Carmen-Pajonal-Machona Lagoon Complex, Tabasco; Mandinga Lagoon, Veracruz; and La Pesca Lagoon, Tamaulipas. The prevalence by PCR and by RFTM is shown for each locality in the pie charts. b Phylogenetic tree inferred by the Maximum Likelihood method (3000 bootstrap replicates) using the 28 rDNA-NTS sequences of Perkinsus marinus in C. virginica from sampled lagoons of the Gulf of Mexico and the GenBank database; the phylogenetic tree with the highest log likelihood (-1922.1161) is shown. There was a total of 308 positions in the final dataset. A rDNA-NTS sequence of P. olseni was used as a root (FJ626860.1). Each colour corresponds to the geographical collection site as well as its haplotype. Red and green colours correspond to $P$. marinus isolates from the Pacific coast of Mexico. Light blue and pink colours correspond to P. marinus isolates from the USA 
oysters) using RFTM (Fig. 1). In total, 18 (24\%) oysters tested positive by both tests. One oyster was positive by RFTM but negative by PCR, while the remaining 17 (22.7\%) oysters were negative by RFTM but positive by PCR $\left(\chi^{2}=23.63, d f=1, P<0.0001\right)$. Sensitivity and specificity using PCR were $94.7 \%$ and $97.5 \%$ and using RFTM, these values were 51.4 and $69.6 \%$, respectively. Infection intensity was light (1-10 hypnospores/field) in 19 oysters, and the WP for this lagoon was 0.25 (Table 1).

\section{La Pesca Lagoon, Tamaulipas}

The prevalence according to PCR was $28.6 \%$ (26 out of 91 oysters), and according to RFTM, it was $19.8 \%$ (18 of 91 sampled) (Fig. 1). In all, 11 (12.08\%) oysters were positive by both tests. Seven organisms were positive by RFTM but negative by PCR. The other 15 (16.5\%) oysters were negative by RFTM but positive by PCR $\left(\chi^{2}=11.64, d f=1, P<0.0001\right)$. Sensitivity and specificity using PCR were $61.1 \%$ and $89.2 \%$, respectively, and by RFTM, they were 42.3 and $79.5 \%$, respectively. Infection intensity was light (1-10 hypnospores/field) in 18 oysters, with a WP of 0.19 (Table 1).

\section{Sequence data and phylogenetic analyses}

The ten phylogenetic rDNA-NTS sequences of $P$. marinus [termed $P$. marinus $(\mathrm{Pm})$ haplotype] found were submitted to GenBank. Two P. marinus rDNA-NTS sequence variants were from the state of Campeche (Términos Pm18 and Términos Pm88), one was from the state of Tabasco (Carmen-Pajonal-Machona Pm1), five were from the state of Veracruz (Mandinga Pm1, Mandinga Pm2, Mandinga Pm3, Mandinga Pm4 and Mandinga Pm5), and two were from the state of Tamaulipas (La Pesca Pm10 \& La Pesca Pm30) (Fig. 1). Nucleotide variability, including deletions and insertions, was observed at 17 positions of the amplified $307 \pm 1$ bp fragment. Table 2 shows the nucleotide position in each rDNA-NTS sequence. These
rDNA-NTS sequences had a maximum identity (96$100 \%$ ) with $18 P$. marinus rDNA-NTS sequences from GenBank. Thus, a total of 28 rDNA-NTS sequences were used for phylogenetic and haplotype network analyses.

Overall, the rDNA-NTS sequences of $P$. marinus from Mexico (sequences from the Mexican coasts of the Gulf of Mexico and sequences from the Mexican Pacific coast) (Clade 1) were observed in a tree branch that had a strong bootstrap support. Clade 1 included three groups (A, B, and C): group "A" included the rDNA-NTS sequences of Carmen-Pajonal-Machona Pm1, Términos Pm88, Términos Pm18 and ten rDNA-NTS sequences reported from the Mexican Pacific coasts (JQ266259.1-JQ266261.1, JQ266252.1-JQ266254.1，JQ266256.1，JQ266257.1 [30]; EU617394.1 [21], and JN676160.1 [31]). Group "B" included the rDNA-NTS sequences from the Gulf of Mexico; Mandinga Pm2, La Pesca Pm10, Mandinga Pm1, Mandinga Pm3, Mandinga Pm4, Mandinga Pm5 and La Pesca Pm30. Group "C" included six rDNA-NTS sequences reported from the Mexican Pacific coast: JQ266255.1, JQ266262.1-JQ266264.1, JQ266251.1, and JQ266258.1 [30] (Fig. 1). Clade 2 was formed by the rDNA-NTS sequences of $P$. marinus from the USA (AF497479.1 [20] and S78416.1) [17]).

The single-level AMOVA analysis for population genetic structuring revealed a highly significant and strong genetic structure among the sampled lagoons $\left(\mathrm{F}_{\mathrm{ST}}=0.45\right.$, $P<0.0001$ ), with $45.17 \%$ of the total genetic variance explained by variation among populations and $54.83 \%$ by variation within populations. Regarding the pairwise $\mathrm{F}_{\mathrm{ST}}$ differences among populations, values ranged from 0.241 to 0.673 , and all comparisons were highly significant $(n=6$ comparisons, $P<0.001)$ (Table 3$)$.

\section{Haplotype network}

In the haplotype network analysis (Fig. 2), sequences from the USA (AF497479.1 and S78416.1) were

Table 2 Nucleotide differences among ten rDNA-NTS sequences of Perkinsus marinus from the Mexican Gulf of Mexico: changes at 17 nucleotide positions are shown, including gaps, insertions, and substitutions

\begin{tabular}{|c|c|c|c|c|c|c|c|c|c|c|c|c|c|c|c|c|c|}
\hline \multirow[b]{2}{*}{ Haplotypes } & \multicolumn{17}{|c|}{ Variation of nucleotide position } \\
\hline & 8 & 9 & 11 & 12 & 20 & 21 & 43 & 65 & 108 & 199 & 296 & 297 & 298 & 299 & 300 & 307 & 308 \\
\hline Carmen-Pajonal-Machona Pm1 & A & $\mathrm{T}$ & - & G & C & A & C & G & $\mathrm{T}$ & A & G & A & G & A & $\mathrm{T}$ & A & A \\
\hline Términos Pm18 & A & A & $\mathrm{T}$ & $\mathrm{T}$ & C & A & C & G & $\mathrm{T}$ & A & G & A & A & $\mathrm{T}$ & $\mathrm{T}$ & A & A \\
\hline Términos Pm88 & A & G & $\mathrm{T}$ & - & C & A & $\mathrm{T}$ & G & $\mathrm{T}$ & A & G & A & A & $\mathrm{T}$ & $\mathrm{T}$ & A & A \\
\hline Mandinga Pm1 & A & $\mathrm{T}$ & - & G & C & $\mathrm{T}$ & $\mathrm{T}$ & A & $\mathrm{T}$ & A & G & A & G & A & $\mathrm{T}$ & A & A \\
\hline Mandinga Pm2 & $\mathrm{T}$ & $\mathrm{T}$ & $\mathrm{T}$ & G & C & $A$ & $\mathrm{~T}$ & G & $\mathrm{T}$ & A & C & A & G & A & $\mathrm{T}$ & A & A \\
\hline Mandinga Pm3 & A & $\mathrm{T}$ & - & G & C & $\mathrm{T}$ & $\mathrm{T}$ & A & $\mathrm{T}$ & A & G & A & G & A & $\mathrm{T}$ & A & G \\
\hline Mandinga Pm4 & A & C & - & G & C & $\mathrm{T}$ & $\mathrm{T}$ & A & $\mathrm{T}$ & A & G & A & G & A & A & A & A \\
\hline Mandinga Pm5 & $\mathrm{T}$ & C & - & $T$ & C & $\mathrm{T}$ & $\mathrm{T}$ & A & $\mathrm{T}$ & A & C & G & A & $\mathrm{T}$ & $\mathrm{T}$ & T & A \\
\hline La pesca Pm10 & A & $\mathrm{T}$ & - & G & $C$ & $\mathrm{~T}$ & $\mathrm{~T}$ & A & $\mathrm{T}$ & A & G & A & G & A & $\mathrm{T}$ & A & A \\
\hline La pesca Pm30 & A & $\mathrm{T}$ & - & G & G & $\mathrm{T}$ & $\mathrm{T}$ & A & G & C & $\mathrm{G}$ & $A$ & $G$ & $A$ & $\mathrm{~T}$ & A & $A$ \\
\hline
\end{tabular}


Table 3 Pairwise estimates of $F_{S T}$ among rDNA-NTS sequences of Perkinsus marinus from the Mexican Gulf of Mexico. F $_{S T}$ estimates are shown below diagonals, and $P$ values are shown above diagonals. Significant $P$-values are indicated by an asterisk

\begin{tabular}{lllll}
\hline Haplotypes & La Pesca & Mandinga & Carmen-Pajonal-Machona & Términos \\
\hline La Pesca & - & $<0.001^{*}$ & $<0.001^{*}$ & $<0.001^{*}$ \\
Mandinga & 0.241 & - & $<0.001^{*}$ & $<0.001^{*}$ \\
Carmen-Pajonal-Machona & 0.647 & 0.500 & - & $<0.001^{*}$ \\
Términos & 0.481 & 0.324 & 0.673 & - \\
\hline
\end{tabular}

separated from the Mexican sequences. Four main haplogroups were observed: haplogroup A, formed by one haplotype from the state of Tabasco (Carmen-PajonalManchona Pm1), included sequences from the Mexican Pacific coast (JQ266252.1, JQ266256.1, JQ266259.1JQ266261.1 [30], EU617394.1 [21] and JN676160.1 [31]) and was closely related to the haplotypes from the Mexican Pacific coast (JQ266253.1, JQ266254.1 and JQ266257.1 [30]). Haplogroup B was formed from sequences from the state of Veracruz and Tamaulipas (Mandinga Pm1, La Pesca Pm10) and was closely connected with haplogroup $\mathrm{C}$, which was formed exclusively from samples from the Mexican Pacific coast (JQ266262.1-JQ266264.1, and JQ266258.1) and related haplotypes JQ266251.1, JQ266255.1 [30]. The two haplotypes from the state of Campeche (Términos Lagoon) (Términos Pm18 and Términos Pm88) formed a separate haplogroup that was distanced from all other
Mexican haplotypes. Mandinga Pm5 was the most differentiated haplotype; it was separated from the nearest haplotype (Mandinga $\mathrm{Pm} 4$ ) by thirteen mutational steps.

\section{Discussion}

Perkinsus marinus impacts on the health and fitness of populations of the oyster $C$. virginica $[1,4,29,32,33]$. Consequently, it is crucial to determine the infection parameters (prevalence, abundance and infection intensity) of this parasite along its geographical distribution. In the lagoons of the Gulf of Mexico that were sampled in this study, the overall prevalence of P. marinus was 57.7\% (338 out of 586 oysters) by PCR and $38.2 \%$ (224 out of 586 oysters) by RFTM. These differences in prevalence in lagoons from the Gulf of Mexico confirm previous studies $[17,34]$ that found that the PCR assay is more sensitive and specific than the RFTM assay to detect $P$. marinus in C. virginica. Robledo et al. [35] obtained

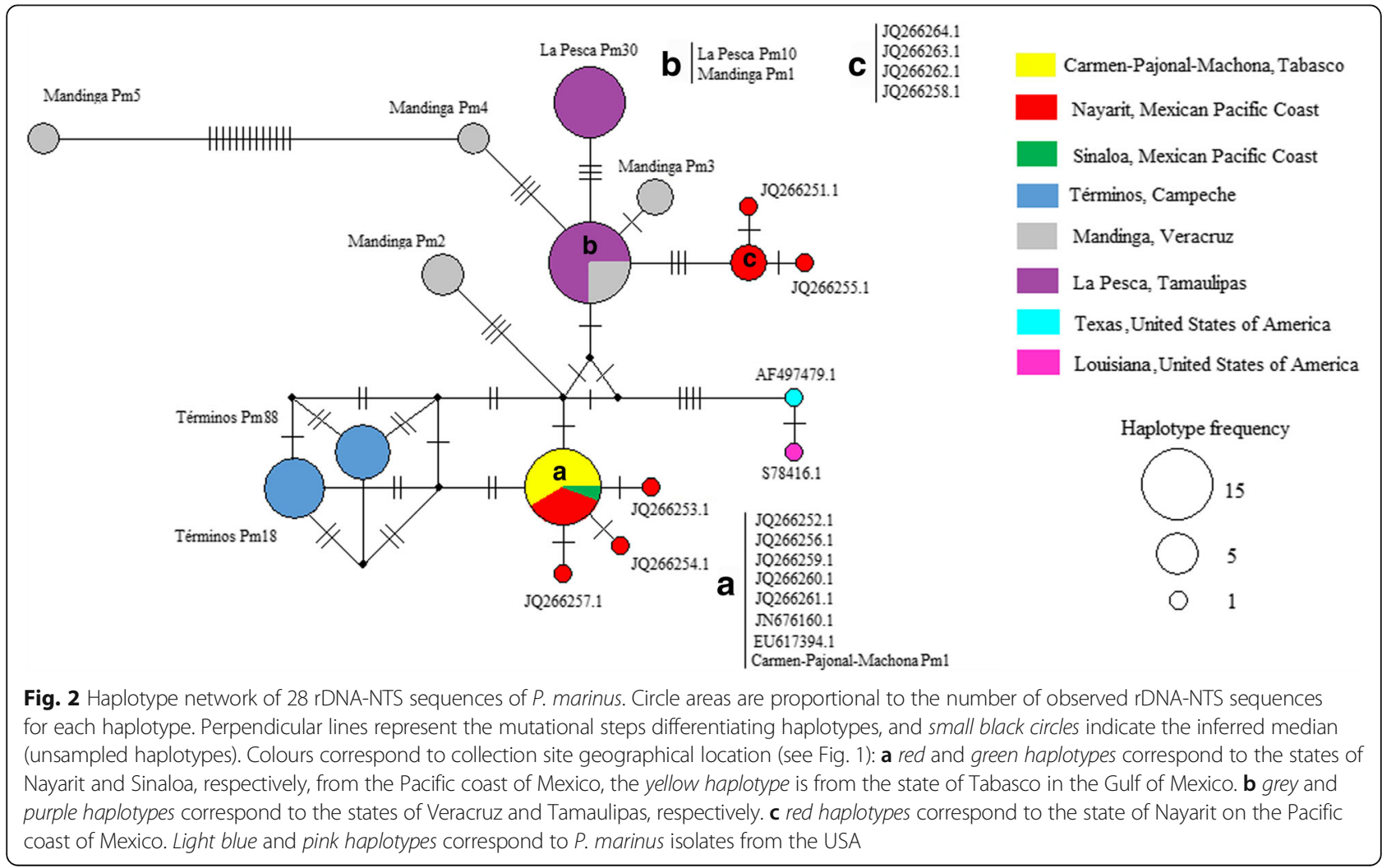


similar results in the USA with the same set of primers. The RFTM assay has limitations in detecting low intensities of $P$. marinus infection, and diagnostic assessment is restricted only to trophozoites and hypnospores stages. In contrast, the PCR can detect low amounts of target DNA during all life stages of $P$. marinus [17, 34]. Both tests can be used to address a new infection in a given area [21], although the high sensitivity and specificity of the PCR test make it a valuable tool to address the prevalence of $P$. marinus in oyster production zones, especially for monitoring early infections [35]. Overall, light parasitic infection was detected in $C$. virginica stocks collected along the four lagoons from the Gulf of Mexico. However, in the Carmen-Pajonal-Machona Lagoon Complex in the state of Tabasco, low (1-10 hypnospores/40× field) to moderate infection intensities (11-100 hypnospores/40× field) with WP values less than one were observed. Scattered reports of mortality have been registered in this region [3], but in the present study, mortality was not quantified. Both tests were highly useful to address the infection. Histology was not used, but in previous research in the zone, this technique was a key factor to detect $P$. marinus infection $[13,14]$. The OIE has stated that to declare a zone Perkinsus-free, it is necessary to use PCR, RFTM, and histology [36].

PCR was performed with specific primers designed from the non-transcribed spacer (NTS) region located between the $5 \mathrm{~S}$ and $18 \mathrm{~S}$ rRNA genes. This region is a highly variable domain, even between closely related species [20]. The ten unique rDNA-NTS sequences that composed the $P$. marinus ( $\mathrm{Pm}$ ) haplotype varied in 17 nucleotide positions and had a length of $307 \pm 1 \mathrm{bp}$. They were similar to 18 rDNA-NTS sequences of $P$. marinus reported in GenBank. At least one DNA variant of $P$. marinus was detected in each lagoon. The major advantage of the PCR test used herein is that it can detect polymorphisms of $P$. marinus attributed to ploidy [37], increasing the possibility of detecting DNA variation due to the recombination of the NTS regions. Perkinsus marinus rDNA-NTS sequences analysed in this work strongly suggest restriction into specific locations, there for the population from each lagoon were genotypical diverse. Although $\mathrm{F}_{\mathrm{ST}}$ values were significant to all lagoons, $P$. marinus from Tabasco state showed the highest differentiation (Table 3). The remaining rDNANTS variants occurred in different areas and exhibited different geographical connections (Fig. 2). The rDNANTS sequences from the USA (Clade 2) were on a different branch from all Mexican NTS sequences that had 94\% bootstrap support (Clade 1). One rDNA-NTS sequence of $P$. marinus infecting $C$. virginica from the state of Tabasco exhibited $100 \%$ similarity with the rDNA-NTS sequences of $P$. marinus infecting native $C$. corteziensis from the state of Nayarit $[21,28,30]$ and $S$. palmula from the state of Sinaloa, on the Pacific coast of Mexico [31]. The phylogenetic tree (Fig. 1) provides evidence of possible gene flow between the Gulf of Mexico and the Mexican Pacific coast. Also, haplotype network analysis revealed that one haplogroup formed entirely from rDNA-NTS sequences from the Mexican Pacific coast was closely related to haplotypes from the states of Veracruz and Tamaulipas, suggesting an alternative route of gene flow. Both phylogenetic tree (Fig. 1) and the haplotype network (Fig. 2) provide evidence of possible gene flow between the Gulf of Mexico and the Mexican Pacific coast.

Mexican oysters are primarily exported to the USA, and the states of Veracruz and Tabasco are the main producers [37]. Tabasco commercializes fresh oysters to other states in Mexico such as Puebla, Oaxaca, Chiapas and Veracruz [38]. There are no documented records of C. virginica introduction into the Pacific coast of Mexico from the Mexican Gulf of México, although CáceresMartínez et al. [21] recorded two routes of introduction of $C$. virginica to the northwest coast of Mexico. One route proceeds from the eastern coast of the USA via the state of Washington and another travel along the east coast of the USA. These authors suggested that $P$. marinus may have been introduced from these places to the Pacific coast. It has been well documented that transport of bivalves from one location to another for aquaculture purposes serves as a mechanical vector for parasitic transmission, contributing to pathogen distribution to regions with non-infected hosts [29, 39-43]. Transferring live oysters is a leading cause of disease outbreaks and epizootics [44].

Before 2006, there were no official reports of P. marinus in Crassostrea species or any other bivalve species along the Mexican Pacific coast. However, in July and August 2006, P. marinus caused massive mortality in farmed C. gigas in the Gulf of California (north-west Mexico) [22]. Moreover, between 2006 and 2014, the parasite was detected in cultured populations of native C. corteziensis oysters from the state of Nayarit [21, 28]. These outbreaks may have occurred due to lack of internal regulations that control the transport of aquatic organisms (i.e. C. virginica) from central Mexico [21, 45]. In subsequent years, $P$. marinus was detected in natural and cultured S. palmula populations in four coastal lagoons in the state of Sinaloa [31]. Despite the destructive effect of $P$. marinus in new environments and host species, no research has focused on the transfer of $P$. marinus from the Gulf of Mexico to the Pacific coast of Mexico.

The successful colonisation of a given parasite in its new environment varies with life-cycle and ability to transfer to local hosts, as well as with natural resistance and resilience in the new hosts and environment. 
Transport and cultivation of oysters have the potential to move organisms between sites [43]. Importantly, the range of parasitic expansion also depends on climate temperature and the genetic variability of the hosts, which regulates tolerance or resistance to the pathogen $[4,23]$. The results from this study strongly suggest parasite transfer from the Gulf of Mexico to the Mexican Pacific coast, most likely via transportation of infected oysters from the state of Tabasco along the Gulf of Mexico.

In the Mexican Pacific coast, $P$. marinus caused high mortality in C. gigas, and high-intensity infections ( 361 to $3,020,516$ hypnospores $g^{-1}$ tissue) were observed [22]. The detrimental effect of $P$. marinus in $C$. gigas could be associated with a DNA variant of the pathogen and the differential susceptibility of C. gigas [46-49]. In the north-eastern coast of the USA, there was evidence of a positive correlation between the increase in death of $C$. virginica stocks and a rise in the prevalence of $P$. marinus [39]. According to the results of the present study, the low to moderate infection intensities observed in $C$. virginica from the Gulf of Mexico could suggest that this parasite's host pathogenicity may be declining in its natural host. However, when transferred to another environment, the pathogenicity increased, as indicated by the high parameters of infection and high mortality described in the Mexican Pacific coast [31, 50]. The $P$. marinus haplotype found in the state of Tabasco (Carmen-Pajonal-Machona Pm1) was identical to rDNA-NTS sequences in other host species from the Mexican Pacific coast. This result also supports the hypothesis that $P$. marinus infection is transient in the Gulf of Mexico (based on the low parasitic infections reported here). The same haplotype was detrimental in the Mexican Pacific coast, based on allegations of mortality and pathogenicity in their new hosts [28]. However, more work must be done to test these preliminary observations.

\section{Conclusions}

Low to moderate $P$. marinus infection intensities were found in C. virginica from the four coastal lagoons along the western and southern coasts of the Gulf of Mexico. PCR was more efficient in detecting cases of $P$. marinus than the RFTM assay. Ten unique $P$. marinus rDNANTS sequences were detected restricted into each specific locations suggesting different populations within subregions (i.e. Tamaulipas and Veracruz), and the remaining rDNA-NTS variants that occurred at different places exhibited different geographical connections. Also, the sequence from the state of Tabasco (CarmenPajonal-Machona Pm1) had high similarity to rDNANTS sequences from the Mexican Pacific coast. Based on the P. marinus DNA molecular NTS variants, we provided information related to the transferal of $P$. mari$n u s$ to new geographical areas (i.e. Mexico's Pacific coast), in native (C. corteziensis and S. palmula) and introduced (C. gigas) oyster species from the Pacific coast of Mexico. This transfer was most likely anthropogenic. Thus, effective regulations are needed to prevent further introduction of notifiable diseases that could potentially expand and devastate non-infected areas and hosts of ecological and economic importance.

\section{Methods}

Sampling sites and oyster collection

A total of 586 C. virginica oysters were collected from four coastal lagoons along the western and southern coasts of the Gulf of Mexico, including the states of Campeche, Tabasco, Veracruz and Tamaulipas (Fig. 1). In March 2005, 120 oysters were collected from Términos Lagoon, Campeche and 300 from the Carmen-PajonalMachona Lagoon Complex, Tabasco. In May 2008, 75 oysters were gathered from Mandinga Lagoon, Veracruz and 91 oysters from La Pesca Lagoon, Tamaulipas.

The oysters were collected either by snorkelling or with the aid of racks. These organisms were transported fresh and alive to the Aquatic Pathology and Molecular Biology Laboratory, CINVESTAV-Mérida. Ten P. marinus-free oysters were obtained from the Hog Island Oyster Company (Marshall, California, USA) and used as negative controls; the negative samples were confirmed by PCR and RFTM of tissue.

After transport to the laboratory, each oyster was dissected with sterile forceps and scissors. Necropsy tools were rinsed and flame-sterilized using 96\% ethanol between sample collections to prevent cross-contamination during sampling. A portion of the rectum, mantle, and gills of each organism was dissected and divided into two portions, each including fragments of these three organs. One portion was incubated in RFTM, and the other portion was preserved in $96 \%$ ethanol for DNA extraction. The infection intensity and weighted prevalence (WP) were determined by RFTM. Prevalence was reported as the percentage of positive organisms based on either RFTM or PCR (see below).

\section{Ray's fluid thioglycollate medium (RFTM) assay}

Tissues were incubated in RFTM for five days at room temperature in darkness, followed by staining with $0.5 \%$ Lugol's iodine. Infection with $P$. marinus was indicated by blue-black pre-zoosporangia (hypnospores, usually $30-80 \mu \mathrm{m}$ in diameter, observed at 40x) (see Ray [32]) for details of technique). The Office International de Épizooties (OIE) considers this procedure to be the gold standard for identification and surveillance of Perkinsus species [36, 51]. 
The infection intensity interpretation using the RFTM assay was performed according to Burreson et al. [1, 3]. Infections were ranked as negative ( 0 hypnospores/field), light (1-10 hypnospores/field), moderate (11-100 hypnospores/field) and heavy (> 100 hypnospores/field) [52] and assigned ratings of $0,1,3$ and 5 , respectively, for the calculation of weighted prevalence (WP) [53]. The prevalence determined by RFTM was used to calculate the WP, which combines prevalence and intensity into a single expression and is determined by adding the individual assigned values and dividing by the number of oysters sampled [54]. WP values less than 1.0 indicate mostly light infections, and values greater than 2.0 indicate high prevalence and severe infection (see Burreson et al. [3]; Aguirre-Macedo et al. [13]; Lassudrie et al. [55]).

\section{Polymerase chain reaction (PCR)-based assay}

Genomic DNA was extracted from $\sim 30 \mathrm{mg}$ of the fixed material using a Wizard Genomic DNA Purification Kit (Promega, Madison, USA). The $P$. marinus-specific PCR was run using the primer set $300 \mathrm{~F}\left(5^{\prime}\right.$-CAC TTG TAT TGT GAA GCA CCC-3'), and 300R (5'-CAG TAA ACC TCT ACA GTG GTT-3') [17], which were designed within the NTS region between the $5 \mathrm{~S}$ and $18 \mathrm{~S}$ rRNA genes. The PCR reactions were performed in a total volume of $25 \mu \mathrm{l}$ containing $1 \mu \mathrm{l}$ genomic DNA (20 ng), $0.2 \mathrm{mM}$ dNTP mixture (Promega), $1 \times$ reaction buffer $(50 \mathrm{mM} \mathrm{KCl}, 10 \mathrm{mM}$ Tris- $\mathrm{HCl}$ [pH 9.0], 0.1\% Triton X-100), each primer at $1 \mathrm{pM}, 0.3 \mathrm{U}$ Taq DNA polymerase (Promega) and $2.5 \mathrm{mM} \mathrm{MgCl}_{2}$.

Amplification conditions were initial denaturation at $91{ }^{\circ} \mathrm{C}$ for $3 \mathrm{~min}, 27$ cycles with a denaturation step at $91^{\circ}$ $\mathrm{C}$ for $1 \mathrm{~min}$, annealing at $58{ }^{\circ} \mathrm{C}$ for $1 \mathrm{~min}$ (increasing $1 \mathrm{~s} /$ cycle), and extension at $72{ }^{\circ} \mathrm{C}$ for $1 \mathrm{~min}$ (increasing $2 \mathrm{~s} /$ cycle); and a final extension cycle was $72{ }^{\circ} \mathrm{C}$ for $10 \mathrm{~min}$. The PCR products were observed on $2 \%$ agarose gels stained with $2 \%$ ethidium bromide and using a 100-bp DNA ladder as a reference (Promega). A band at $307 \mathrm{bp}$ was considered a positive result for $P$. marinus infection [35]. A negative control (DNA from P. marinus-free $C$. virginica tissues) was used in all assays. Crosscontamination was avoided by individually processing each sample under sterile conditions in a laminar flow cabinet. Prevalence was considered the percentage of oysters with a positive band at 307 bp (see Bush et al. [56].

\section{Statistical analysis}

Chi-square $(2 \times 2)$ test with Yates' correction and twotailed Fisher's exact tests using 95\% confidence intervals (CI) were used to evaluate differences in the proportion of infection [57]. The significance of the differences in infection prevalence between lagoons was assessed using G-tests [58], with significance established at $P=0.05$. Sensitivity and specificity were calculated in the same conventional chi-square test, considering as RFTM as a gold standard test. Sensitivity (also called the true positive rate). Sensitivity measures the proportion of positives that are correctly identified as such and were calculated using the formula: Sensitivity $=\mathrm{TP} / \mathrm{TP}+\mathrm{FN}$. Specificity measures the proportion of negatives that are correctly identified as such and was calculated with the formula: Specificity $=$ TN/TN + FP. True positives $(\mathrm{TP})$ were those RFTM-, and PCR-diagnosed as positive. False positives (FP) were those RFTM diagnosed as negative but PCR as positive. False negatives (FN) were those RFTM diagnosed as positive, but PCR as negative. True negatives (TP) were those RFTM, and PCR diagnosed as negative $[59,60]$. The analyses were performed using STATISTICA 8 software of Stat Soft, Inc. 1984-2007.

\section{Sequencing and phylogenetic analysis}

DNA sequences were obtained using an automatic sequencer (Applied Biosystems, Mod. ABI 310) [61]. They were then analysed and edited with the Chromas Pro V.1.2 program (Technelysium Pty. Ltd., 2009) and aligned with Clustal X (2.0.12) software [62]. Unique $P$. marinus rDNA-NTS sequences [termed $P$. marinus (Pm) haplotype] were compared to DNA sequences from GenBank (https://www.ncbi.nlm.nih.gov/ncbisearch) to determine homology. Total rDNA-NTS sequences were used to construct the phylogenetic tree. The statistical model most suited to measuring divergence between rDNA-NTS $P$. marinus sequences obtained in this study and homologous rDNA-NTS sequences from the GenBank were assessed using Model Test 3.7 software [63]. Divergence was estimated using the Maximum Likelihood method under the General Time Reversible model with 3000 bootstrap randomizations [64]. A heuristic search tree was automatically generated using the Neighbour-Joining and BioNJ algorithms, which created a pairs distance matrix that was estimated using the Maximum Composite Likelihood (MCL) method. The topology, with the superior log likelihood value selected, was used to analyse all DNA sequences, including gaps and deletions. Perkinsus olseni was used as root (FJ626860.1). Statistical analyses (95\% confidence intervals) used in tree construction were performed using MEGA 7 software [65]. Arlequin 3.5 software [66] was used to estimate population differentiation, calculating the pairwise $\mathrm{F}_{\mathrm{ST}}$ values among sampled populations (coastal lagoons), and performing a hierarchical analysis of molecular variance (AMOVA) [67]. Significance values were calculated using 10,000 random permutations.

\section{Haplotype network}

Relationships between $P$. marinus haplotypes and base pair changes were observed by constructing a haplotype 
network using the same rDNA-NTS sequences from $P$. marinus identified here and in the GenBank database. The haplotype network was calculated using the Median-Joining algorithm, applied with the NetWork v.4.6.1.2 software [68].

\section{Abbreviations}

NTS: non-transcribed spacer; PCR: polymerase chain reaction; Pm: Perkinsus marinus; rDNA: ribosomal DNA; RFTM: Ray's fluid thioglycollate medium; WP: weighted prevalence

\section{Acknowledgements}

The authors thank Dr. Eugene M. Burreson for providing Perkinsus-free oyster tissue, and the personnel of the Veterinary School of the Universidad Autónoma de Tamaulipas (UAT) for providing oysters from La Pesca lagoon.

\section{Funding}

The research reported here was funded by the projects "Determinación del estado sanitario (diagnosis, histológico, parasitológico y microbiológico) del ostión Crassotrea virginica en los principales bancos ostrícolas del complejo lagunar Carmen-Pajonal-Machona" (SAGARPA No. 1203) granted do MLAM, "Programa de monitoreo ambiental del sur del Golfo de México" (Campañas Oceanográficas 2-2005 and SGM No. 10-2005, Xcambó-2, reference numbers: $428,816,811$ \& 418,815,846), and funds generated by external services provided at the Laboratory of Immunology and Molecular Biology granted to RRC.

\section{Availability of data and materials}

All the rDNA sequences are available through the GenBank. Tissue samples are kept frozen in our facilities and available on request. Metadata are kept in Excel datasheets in our laboratories and are available on request.

\section{Authors' contributions}

JEH participated in the study design, collected and analysed the samples, undertook the data analyses and drafted the manuscript. RRC conceived and participated in the study design, wrote the manuscript (Ms) and provided reagents. MAM designed the study, provided reagents and coordinated the field studies. MAP constructed the haplotype network, helped with the writing of the Ms. WM corrected several versions of the Ms. JPV helped with the experiments. RSA helped with the experiments and data interpretation. IJG helped with the sample collections from Veracruz, discussed the results and helped with the writing of the Ms. RZB helped with the interpretation of the data and in the writing of the Ms. All authors read and approved the final manuscript.

\section{Ethics approval and consent to participate}

Not applicable. Oysters were collected from Lagoons where they are cultured for human consumption. We had a sampling license issued by SAGARPA (Official council for agriculture, fisheries, and livestock) (Ref. 1203).

\section{Consent for publication}

Not applicable.

\section{Competing interests}

The authors declare that they have no competing interests.

\section{Publisher's Note}

Springer Nature remains neutral with regard to jurisdictional claims in published maps and institutional affiliations.

\section{Author details}

'Laboratorio de Inmunología y Biología Molecular, Centro de Investigación y de Estudios Avanzados del IPN (CINVESTAV-IPN) Unidad Mérida, Carretera Antigua a Progreso Km. 6, 97310 Mérida, Yucatán, Mexico. ${ }^{2}$ Laboratorio de Patología Acuática, Centro de Investigación y de Estudios Avanzados del IPN (CINVESTAV-IPN) Unidad Mérida, Carretera Antigua a Progreso Km. 6, 97310 Mérida, Yucatán, Mexico. ${ }^{3}$ Instituto Tecnológico de Boca del Rio, Carretera Veracruz-Córdoba Km. 12, 94290 Boca del Río, Veracruz, Mexico. ${ }^{4}$ Instituto Tecnológico de Conkal, Antigua Carretera Mérida-Motul Km. 16.3, 97345 Conkal, Yucatán, Mexico.
Received: 19 September 2016 Accepted: 24 July 2017

Published online: 02 August 2017

\section{References}

1. Burreson EM, Ragone-Calvo LM. Epizootiology of Perkinsus marinus disease of oysters in Chesapeake Bay, with emphasis on data since 1985. J Shellfish Res. 1996;15:17-34.

2. Andrews JD. Epizootiology of diseases of oysters (Crassostrea virginica), and parasites of associated organisms in eastern North America. Helgoländer Meeresun. 1984;37:149-66.

3. Burreson EM, Sima-Alvarez R, Vidal-Martinez V, Aguirre-Macedo L. Perkinsus marinus (Apicomplexa) as a potential source of oyster Crassostrea virginica mortality in coastal lagoons of Tabasco, Mexico. Dis Aquat Org. 1994;20:77-82.

4. Ford S. Range extension by the oyster parasite Perkinsus marinus into the northeastern United States: response to climate change? J Shellfish Res. 1996;15:45-56.

5. Soniat TM. Epizootiology of Perkinsus marinus disease of eastern oysters in the Gulf of Mexico. J Shellfish Res. 1996;15:35-45.

6. Andrews JD. History of Perkinsus marinus, a pathogen of oysters in Chesapeake Bay 1950-1984. J Shellfish Res. 1996;15:13-6.

7. Reece K, Brown G, Hudson K, Apakupakul K. Inter- and intra-specific genetic variation among Perkinsus species: implications for species identification and development of molecular diagnostics. J Shellfish Res. 2001;20:554.

8. Kern FG, Sullivan LC, Takata M. Labyrinthomyxa-like organisms associated with mass mortalities of oysters, Crassostrea virginica, from Hawaii. Natl Shellfish Assoc Conv. 1973;63:43-6.

9. Da Silva PM, Scardua MP, Vianna RT, Mendonça RC, Vieira CB, Dungan CF, et al. Two Perkinsus spp. infect Crassostrea gasar oysters from cultured and wild populations of the Rio São Francisco estuary, Sergipe, northeastern Brazil. J Invertebr Pathol. 2014;119:62-71.

10. Dantas-Neto MP, Sabry RC, Ferreira LP, Romão LS, Maggioni R. Perkinsus sp. infecting the oyster Crassostrea rhizophorae from estuaries of the septentrional northeast, Brazil. Braz J Biol. 2015;75:1030-4.

11. da Silva PM, Vianna RT, Guertler C, Ferreira LP, Santana LN, Fernández-Boo S, et al. First report of the protozoan parasite Perkinsus marinus in South America, infecting mangrove oysters Crassostrea rhizophorae from the Paraíba River (NE, Brazil). J Invertebr Pathol. 2013;113:96-103.

12. Pagenkopp-Lohan KM, Hill-Spanik KM, Torchin ME, Aguirre-Macedo L, Fleischer RC, Ruiz GM. Richness and distribution of tropical oyster parasites in two oceans. Parasitology. 2016:1119-32.

13. Aguirre-Macedo ML, Simá-Álvarez RA, Román-Magaña MK, Güemez-Ricalde Jl. Parasite survey of the eastern oyster Crassostrea virginica in coastal lagoons of the southern Gulf of Mexico. J Aquat Anim Health. 2007;19:2709.

14. Gullian-Klanian M, Herrera-Silveira JA, Rodríguez-Canul R, Aguirre-Macedo L. Factors associated with the prevalence of Perkinsus marinus in Crassostrea virginica from the southern Gulf of Mexico. Dis Aquat Org. 2008;79:237-47.

15. Huicab-Pech ZG, Curiel-Ramírez S, Castañeda-Chávez M, Lango-Reynoso F, Carrillo-Alejandro P. Variación estacional de Perkinsus marinus en el ostión americano Crassostrea virginica del sistema lagunar Carmen-MachonaPajonal en Tabasco, México. Trop Subtrop Agroecosystems. 2012;15:S40-50.

16. Gutiérrez-Rivera JN, Arcos-Ortega GF, Luna-González A, Rodríguez-Jaramillo MC, Arechiga-Carvajal ET, Vázquez-Juárez R. Differential expression of serine protease inhibitors 1 and 2 in Crassostrea corteziensis and C. virginica infected with Perkinsus marinus. Dis Aquat Org. 2015;112:185-97.

17. Marsh AG, Gauthier JD, Vasta GR. A semiquantitative PCR assay for assessing Perkinsus marinus infections in the eastern oyster, Crassostrea virginica. J Parasitol. 1995:81:577-83.

18. Ford S, Tripp M. Diseases and defense mechanisms. In: Kennedy VS, Newell RIE, Eble AF, editors. The eastern oyster: Crassostrea virginica. Maryland: Maryland Sea Grant College; 1996. p. 581-660.

19. Reece KS, Dungan CF, Burreson EM. Molecular epizootiology of Perkinsus marinus and $P$. chesapeaki infections among wild oysters and clams in Chesapeake Bay, USA. Dis Aquat Org. 2008;82:237-48.

20. Robledo JA, Wright AC, Marsh AG, Vasta GR. Nucleotide sequence variability in the nontranscribed spacer of the rRNA locus in the oyster parasite Perkinsus marinus. J Parasitol. 1999;85:650-6.

21. Cáceres-Martínez J, Vásquez-Yeomans R, Padilla-Lardizábal G, del Río Portilla MA. Perkinsus marinus in pleasure oyster Crassostrea corteziensis from Nayarit, Pacific coast of México. J Invertebr Pathol. 2008;99:66-73. 
22. Enríquez-Espinoza TL, Grijalva-Chon JM, Castro-Longoria R, Ramos-Paredes J. Perkinsus marinus in Crassostrea gigas in the Gulf of California. Dis Aquat Org. 2010;89:269-73.

23. Bushek D, Allen SK Jr. Host-parasite interactions among broadly distributed populations of the eastern oyster Crassostrea virginica and the protozoan Perkinsus marinus. Mar Ecol Prog Ser. 1996;139:127-41.

24. Bushek D, Allen SK Jr. Races of Perkinsus marinus. J Shellfish Res. 1996;15: 103-7.

25. Yee A, Dungan C, Hamilton R, Goedken M, Guise SDE, Sunila I. Apoptosis of the protozoan oyster pathogen Perkinsus marinus in vivo and in vitro in the Chesapeake Bay and the Long Island Sound. J Shellfish Res. 2005;24:1035-42.

26. Panko C, Encomio V, Barreto J, Volety AK. In vitro and in vivo evaluation of quinine as a potential anti-protozoal for the eastern oyster parasite Perkinsus marinus. J Shellfish Res. 2008;27:789-93.

27. Reece K, Bushek D, Hudson K, Graves J. Geographic distribution of Perkinsus marinus genetic strains along the Atlantic and gulf coasts of the USA. Mar Biol. 2001;139:1047-55.

28. Cáceres-Martínez J, Madero-López LH, Padilla-Lardizábal G, VásquezYeomans R. Epizootiology of Perkinsus marinus, parasite of the pleasure oyster Crassostrea corteziensis, in the Pacific coast of Mexico. J Invertebr Pathol. 2016;139:12-8.

29. Brenner M, Fraser D, Van Nieuwenhove K, O'Beirn F, Buck BH, Mazurié J, et al. Bivalve aquaculture transfers in Atlantic Europe. Part B: environmental impacts of transfer activities. Ocean Coast Manag. 2014;89:139-46.

30. Escobedo-Fregoso C, Arzul I, Carrasco N, Gutiérrez-Rivera JN, Llera-Herrera R, Vázquez-Juárez R. Polymorphism at the ITS and NTS loci of Perkinsus marinus isolated from cultivated oyster Crassostrea corteziensis in Nayarit, Mexico and phylogentic relationship to P. marinus along the Atlantic Coast. Transbound Emerg Dis. 2015;62:137-47.

31. Cáceres-Martínez J, García-Ortega M, Vásquez-Yeomans R, Pineda-García Tde J, Stokes NA, Carnegie RB. Natural and cultured populations of the mangrove oyster Saccostrea palmula from Sinaloa, Mexico, infected by Perkinsus marinus. J Invertebr Pathol. 2012;110:321-5.

32. Ray S. Historical perspective on Perkinsus marinus disease of oyster in the Gulf of Mexico. J Shellfish Res. 1996;15:9-11.

33. Powell EN, Ashton-Alcox KA, Kraeuter JN, Ford SE, Bushek D. Long-term trends in oyster population dynamics in Delaware Bay: regime shifts and response to disease. J Shellfish Res. 2008;27:729-55.

34. Burreson EM. Misuse of PCR assay for diagnosis of mollusc protistan infections. Dis Aquat Org. 2008:80:81-3.

35. Robledo JA, Gauthier JD, Coss CA, Wright AC, Vasta GR. Species-specificity and sensitivity of a PCR-based assay for Perkinsus marinus in the eastern oyster, Crassostrea virginica: a comparison with the fluid thioglycollate assay. J Parasitol. 1998;84:1237-44.

36. OIE. Validation guideline 3.6.3. Development and optimisation of nucleic acid detection assays. 2014;1-10. http://www.oie.int/fileadmin/Home/eng/ Health_standards/aahm/current/GUIDELINE_3.6.3_NAD_ASSAYS.pdf. Accessed 22 May 2017.

37. Thompson PC, Rosenthal BM, Hare MP. An evolutionary legacy of sex and clonal reproduction in the protistan oyster parasite Perkinsus marinus. Infect Genet Evol. 2011;11:598-609.

38. SAGARPA. Comité de Sanidad Acuícola del Estado de Tabasco, A.C: Diagnostico de situación sanitaria acuícola del estado de Tabasco. Ostión. http://www.gbcbiotech.com/genomicaypesca/documentos/moluscos/. Accessed 22 May 2017.

39. Ford SE, Smolowitz R. Infection dynamics of an oyster parasite in its newly expanded range. Mar Biol. 2007;151:119-33.

40. Muehlbauer F, Fraser D, Brenner M, Van Nieuwenhove K, Buck BH, Strand O, et al. Bivalve aquaculture transfers in Atlantic Europe. Part A: Transfer activities and legal framework. Ocean Coast Manag. 2014;89:127-38.

41. Polley $L$, Thompson A. Parasites and wildlife in a changing world. Trends Parasitol. 2015;31:123-4.

42. Williams CF, Britton JR, Turnbull JF. A risk assessment for managing nonnative parasites. Biol Invasions. 2013;15:1273-86.

43. Cohen AN, Zabin CJ. Oyster shells as vectors for exotic organisms. J Shellfish Res. 2009;28:163-7.

44. Aranguren R, Figueras A. Moving from histopathology to molecular tools in the diagnosis of molluscs diseases of concern under EU legislation. Front Physiol. 2016;7:538.
45. Cáceres-Martínez J, Vásquez-Yeomans R, Padilla-Lardizábal G. Parasites of the pleasure oyster Crassostrea corteziensis cultured in Nayarit, Mexico. J Aquat Anim Health. 2010;22:141-51.

46. Grech K, Watt K, Read AF. Host-parasite interactions for virulence and resistance in a malaria model system. J Evol Biol. 2006;19:1620-30.

47. Mackinnon MJ, Gaffney DJ, Read AF. Virulence in rodent malaria: host genotype by parasite genotype interactions. Infect Genet Evol. 2002;1:287-96.

48. Salvaudon L, Héraudet V, Shykoff JA. Genotype-specific interactions and the trade-off between host and parasite fitness. BMC Evol Biol. 2007;7:189.

49. Salvaudon $L$, Héraudet $V$, Shykoff JA. Parasite-host fitness trade-offs change with parasite identity: genotype-specific interactions in a plant-pathogen system. Evolution. 2005;59:2518.

50. Enríquez-Espinoza TL, Grijalva-Chon JM. Variabilidad genética de Crassostrea gigas y Crassostrea corteziensis de un laboratorio de producción del noroeste de México. Cienc Mar. 2010;36:333-44.

51. McGladdery SE, Cawthorn RJ, Bradford BC. Perkinsus karlssoni n. sp. (Apicomplexa) in bay scallops Argopecten irradians. Dis Aquat Org. 1991;10: 127-37.

52. Ray SM. Biological studies of Dermocystidium marinum. Rice Inst Pam. 1954. p. 114.

53. Mackin JG. Oyster disease caused by Dermocystidium marinum and other microorganisms in Louisiana. Publ Inst Mar Sci. 1962:132-229.

54. Andrews JD. Epizootiology of the disease caused by the oyster pathogen Perkinsus marinus and its effects on the oyster industry. Am Fish S S. 1988. p. 47-63.

55. Lassudrie M, Wikfors GH, Sunila I, Alix JH, Dixon MS, Combot D, et al. Physiological and pathological changes in the eastern oyster Crassostrea virginica infested with the trematode Bucephalus sp. and exposed to the toxic dinoflagellate Alexandrium fundyense. J Invertebr Pathol. 2015;126:5163.

56. Bush A, Lafferty A, Lotz J, Shostak A. Parasitalogy meets ecology on its own terms: Margolis et al. revisited. J Parasitol. 1997:83:575-83.

57. StatSoft Inc. Statistica (data analysis software system), version 8.0. www. statsoft.com. 2007;2007.

58. Sokal RR, Rohlf FJ. Biometry. Second. Freeman WH, editor. San Francisco: WH Freeman and Co. NY; 1998

59. Parikh R, Mathai A, Parikh S, Sekhar GC, Thomas R. Understanding and using sensitivity, specificity and predictive values. Indian J Ophthalmol. 2008;56: 45-50.

60. Stojanović M, Apostolović M, Stojanović D, Milošević Z, Toplaović A, Lakušić Mitić $V$, et al. Understanding sensitivity, specificity and predictive values. Vojnosanit Pregl. 2014;71:1062-5.

61. Sanger F, Nicklen S, Coulson AR. DNA sequencing with chain-terminating inhibitors. Proc Natl Acad Sci USA. 1977;74:5463-7.

62. Thompson JD, Gibson TJ, Plewniak F, Jeanmougin F, Higgins DG. The CLUSTAL X windows interface: flexible strategies for multiple sequence alignment aided by quality analysis tools. Nucleic Acids Res. 1997;25:4876_82

63. Posada D, Crandall KA. MODELTEST: testing the model of DNA substitution. Bioinformatics. 1998;14:817-8.

64. Nei M, Kumar S. Molecular evolution and phylogenetics. New York: Oxford University Press; 2000.

65. Kumar S, Stecher G, Tamura K. MEGA7: Molecular Evolutionary Genetics Analysis version 7.0 for bigger datasets. Mol Biol Evol. 2016;33:msw054.

66. Excoffier L, Laval G, Schneider S. Arlequin (version 3.0): an integrated software package for population genetics data analysis. Evol Bioinforma. 2005;1:47-50.

67. Excoffier L, Smouse PE, Quattro JM. Analysis of molecular variance inferred from metric distances among DNA haplotypes: application. Genetics. 1992; 131:479-91.

68. Bandelt HJ, Forster $P$, Röhl A. Median-joining networks for inferring intraspecific phylogenies. Mol Biol Evol. 1999;16:37-48. 